\title{
CONTRACTUAL OBLIGATIONS ANALYSIS FOR CONSTRUCTION WASTE MANAGEMENT IN CANADA
}

\author{
Daylath MENDIS ${ }^{\mathrm{a}}$, Kasun N. HEWAGE ${ }^{\mathrm{a}}$, Joanna WRZESNIEWSKI ${ }^{\mathrm{b}}$ \\ ${ }^{a}$ School of Engineering, Okanagan campus, University of British Columbia, \\ EME 3211, 1137 Alumni Avenue, Kelowna, BC, Canada, V1V 1V7BC, Canada \\ ${ }^{b}$ Joanna E. Wrzesniewski Law Corporation, Suite 202 - 1433 St. Paul Street, \\ Kelowna, BC, V1Y 2E4 Kelowna, BC, Canada
}

Received 23 Sep 2012; accepted 19 Feb 2013

\begin{abstract}
Construction industry creates a massive amount of waste, which typically ends up in landfills. Canadian construction industry represents $30 \%$ of the total municipal solid waste deposited in landfills. Construction and demolition (C\&D) waste has created negative socioeconomic and environmental impacts including contaminating ground water, emitting greenhouse gases, and adding more waste to scarce landfills. Literature is cited rework/waste generation due to ambiguity/errors in construction contract documents. Exculpatory clauses in contract documents are included in contractual agreements to prevent contractor claims, which often cause rework. After an extensive contract documents review, these clauses were categorized in to eight major areas. This paper (1) analyses expert opinions on pre-identified contractual clauses; and (2) introduces recommendations to minimize rework and waste in construction projects. It was found that the clauses related to quality, workmanship, and field quality control/inspection have the most potential to generate construction waste.
\end{abstract}

Keywords: construction waste, construction waste management, disclaimer clauses, rework, contractual agreements, analytic hierarchy process (AHP), attribute weighing method (AWM).

\section{Introduction}

Almost all industries in Canada are influenced by strict environmental regulations. The construction industry is not an exception. The Canadian construction industry is a large contributor of waste materials to landfills. In reality, landfills are rapidly approaching their capacity. As a result, the cost of disposal of waste is rising. In highly populated areas, replacing landfills is difficult due to the public anxiety over social and environmental impacts (The Canadian Construction Association 1992).

Mendis and Hewage (2011) found several incidents of rework initiated due to certain contractual clauses in commercial construction contracts. The same authors mentioned that limited research studies related to the contractual clauses and their impact on rework (and waste) in published literature. Apart from Mendis and Hewage (2011), the authors could not locate any published research study related to the contractual clauses and their impact on construction waste. This paper aims to fill up this knowledge gap by conducting further research and analysis.

The authors reviewed numerous contractual agreements, several project contract documents, and specifications in Canada. Following contractual agreements (in Canada) were carefully reviewed in this research:
- Owner/Contractor agreements;

- Owner/Design-Builder agreements;

- Owner/Construction Manager agreements;

- Design-Builder/Contractor agreement;

- Contractor/Sub contractor agreements;

- Design-Builder/Architect agreements;

- Architect/Consultant agreements;

- Owner/Architect agreements.

It was noted that several clauses in the technical specifications and general conditions in contractual agreements have impacts on generating rework/waste. Such clauses were categorised in to eight major areas i.e. quality, substitution, workmanship, geotechnical report, submittals/shop drawings, field quality control/inspection, shop finish, and temporary or trial usage/testing. Authors' professional practice also noted several incidents of rework/waste generation due to certain contractual clauses, which have fallen into the identified eight categories.

The overall objective of this paper is to analyse the impacts of standard contractual clauses in generating construction waste and rework in Canada. Data related to this study was collected through literature reviews, interviews, questionnaire surveys, and on-site observations. 
The paper is concluded with suggestions to amend the standard Canadian contract documents, to minimize rework/waste in construction projects. This paper intends to provide suggestions and recommendations to the lawyers, who formulate construction contracts. A future validation study is suggested in this area, once the noted suggestions are implemented in the industry.

\section{Background}

Riches and Dancaster (2004) stated that the personal judgment which is intended to resolve disputes can be a risk for a project. Terms like "to the satisfaction of architect/contract administrator/engineer" are models for this type of provisions. In addition, implied terms in contracts can cause conflicts or disputes due to misinterpretation in the contract document (Eggleston 2004). Love et al. (2009) stated that ambiguous communication, such as not providing clear instruction on what, when, and how a task is to be done, may result rework later. The same phenomenon had been echoed by Love et al. (2010), and they revealed that clearly defined working procedures and communications may positively effect in reducing rework and waste. These studies urged the necessity of contract documents with clear instructions.

Jergeas and Hartman (1996) mentioned that the owner's ideas are communicated to contractors through contract clauses mentioned in the bid or contract documents. Poorly written and ambiguous contract documents have a tendency for misinterpretation by the other parties. As per the same researchers, the owners usually incline to contractually transfer responsibilities of numerous project risks to the contractors through disclaimer clauses. These unfair risk allocations in contract agreements create disputes (Powell-Smith, Sims 1990; Bosche 1978; Vidogah, Ndekugri 1997; Loosemore 1999). The most important risks in construction are: 1) construction rework (waste) and modifications; 2) design errors and omissions; 3) change orders; 4) delay damages; 5) overlooked work (assigned to no party); and 6) cost overrun and inaccurate cost estimating (Moazzami et al. 2011). Besides, Li and Taylor (2011) recommended that all the stakeholders involved in a project must realize the possible result of having unnoticed rework (waste). They must collaborate towards the final project goal. However, this goal may be achieved by a contractual agreement that do not transfer the responsibilities in unfair manner.

Doloi et al. (2011) have found that the substandard contracts; hence, rework due to changes, as a significant factor that delays projects. Love et al. (2008) mentioned that errors are inevitable in contract documentation. As per the general practice, the same researchers stated that the errors in contract documentation are assumed to be identified by the contractors/subcontractors. The same researchers concluded that the most significant factor influence cost and time overruns in construction is rework (waste), which typically expresses itself in the form of changes and errors. Further, Hwang et al. (2009) have found that owners incline to report rework (sources of waste) more as constructor's errors/omissions, and contractors more frequently point the need for rework to design errors/omissions. Hwang et al. (2009) recommended developing a tracking system for controlling constructor's errors/omissions for owners; design changes for contractors; and owner changes and design errors/omissions for both owners and contractors. As per the same authors, the processes of reviewing shop drawings, site inspections, and checking the drawings and the contract documents for errors should be a part of this process; then, the consultants are bound to take the responsibility of the work they have reviewed and inspected.

Love (2002) concluded that clients' demand to cut the time available for design and premature production of contract documentation impact the quality of contract documentation. As a result, errors and omissions of contract documentation may cause rework (and waste). The same fact had been echoed by Love and Sohal (2003), and they have found that the consultants only work on a project for the time they had budgeted for their fee. As a result, dimensional errors and omissions happen during the construction phase, particularly at the interface between subcontract trades.

Change orders and rework are more common in fasttrack projects than regular projects. Currently, fast-track projects lack in sufficient specific provisions and clauses in contract agreements that reasonably assign risks between stakeholders. In fast-tracking, incomplete drawings and specifications in bid packages, submitted to subcontractors or trade contractors, cause inevitable rework and changes in the next stages of projects (Moazzami et al. 2011).

Ahzahar et al. (2011) stated that the quality of site supervision has a key impact on the overall performance and productivity of construction projects. Bossink and Brouwers (1996) mentioned that problems in specifications, related to the quality, as a key reason for waste generation. Insufficient supervision is believed to be another reason for rework and waste. These statements can be justified by reviewing the Canadian contractual clauses, which are written to assure the quality of work. The exculpatory clauses are written to mention that; continuous checking of quality is not a requirement of the consultant; the decisions on the quality of work are based on the consultant's judgement; and quality of the work is strictly under the responsibility of the contractor regardless of the consultant tested the work or not (CCDC 2-2008). Moreover, less attention to quality assertion may result in decrease in quality assertion efficiency, which would result in some errors passing undetected, and being approved as correctly completed work. Then the defective work that is accepted is referred as undiscovered rework (Li, Taylor 2011).

$\mathrm{Lu}$ and Yuan (2010) mentioned that fast designs and inadequate market information create more design changes. The same researchers stated that improving the coordination among designers, and close coordination among de- 
signers and contractors are all helpful in reducing design changes. In addition, Love and Sohal (2003) have found that poor coordination and incorporation between design team members obstruct the information flow. Moreover, $\mathrm{Lu}$ and Yuan (2011) stated construction and demolition waste management is a multidisciplinary effort, which requires coordination of different disciplines, including the legal profession.

Fayek et al. (2003) reported that frequent rework incidents occur in construction projects to correct errors initially happened in the fabrication yard. These errors could have been avoided by a sound shop drawing checking process. Bossink and Brouwers (1996) noted that the limited knowledge in construction and constructability, during the project design stage, is the main reason for waste generation. Lu et al. (2011) found that a certain amount of concrete waste was generated due to the use of pre-fabricated concrete piles, which were made with a standard length.

As noted above, literature cited errors, deficiencies, risk transfer, ambiguity, and disputes in contractual agreements cause rework. In addition, this research proved the potentials to create rework (and construction waste) due to the unfair disclaimer clauses.

\section{Methodology}

A pilot study was conducted in the initial phases of the research to determine the epistemological approach of this research. Identified clauses in the Canadian contract documents were classified as shown in Table 1.

Field observations were very important in this type of research, since it gives the practical validity for the study. In this research, four commercial construction projects in British Columbia, Canada were observed for a 10 months period. The total construction costs of the observed projects were \$68 million, \$31 million, \$42 million, and $\$ 15$ million (Canadian dollars). "Construction Project Management" delivery method was used in all of these projects.

During regular site visits, all the visible waste items and relevant sources of waste were identified. Investigations and inquiries were conducted to determine whether these waste items were generated due to deficiencies in the contract documents. In addition, "what-if" analysis was conducted to check the possibilities of avoiding waste by amending the current contract documents. Important conclusions and recommendations were drawn from this process, and they are included in the conclusions and recommendations section of this paper.

In addition to observations, one of the nonprobability sampling methods - expert sampling method - was used to collect data from open-ended discussions/interviews and questionnaires surveys. By combining random sampling and expert sampling methods, external validity concerns were addressed. Expert sampling method - a specific subcase of purposive sampling - is the best way to elicit the views of persons who have experience and insight into the field (Trochim 2000). Two hundred and nine questionnaires were disseminated to randomly selected consulting/construction/architectural companies in Canada. Initially, the questionnaire was sent in MS Word format; then, it was sent in pdf format (pdf fillable forms). Finally, the "Survey Monkey" web facility was used, since some of the participants expressed their desire to participate in an online survey. The response rate was about $22 \%$ with all three methods. Table 2 shows the sample distribution of the participants of questionnaire survey and open-ended discussions/interviews. The majority of the respondents were construction professionals, who directly manage construction projects. These professionals (i.e. project managers, project coordinators) are the first-hand users of construction agreements in construction settings.

An interview usually took about 30-45 minutes for a single participant. Fifteen interviews were conducted. The interview questions are in the Appendix 1. The results of open-ended discussions/interviews are also presented in the conclusions and recommendations section of this paper. Research participants were asked to prioritize the contractual clause categories, given in Table 1, in terms of waste generating potential. These categories have been indicated, individually and in a pairwise manner, in the parts 1 and 2 of the questionnaire. With this process, the required rankings and pairwise comparisons were obtained. The final values were taken by averaging all questionnaires that individually pass the consistency test. Attribute weighing method (AWM) and group decision method were used to rank the selected contractual clause categories. Moreover, risk ratio was also calculated by using AHP to highlight risks of the contractual clause categories that have the maximum potential to create construction waste. Clause prioritization was conducted to justify the urgency for changes/modifications or deletions in contract clauses. Figure 1 summarizes the research methodology and activity plan.

\section{Data analysis methods}

As mentioned above, pre-identified contractual clauses were prioritized with expert opinions. Group decision method and Attributed Weighted Method (AWM) were used as prioritization tools. Using these two parallel measures, convergent validity - parallel-forms reliability can be achieved. Moreover, this procedure eliminates the sources of errors caused by biases (Trochim 2000).

\subsection{Application of analytical hierarchy process (AHP) and group decision method}

Figure 2 illustrates the hierarchical structure of the AHP. The crux of AHP is to rank the potential contractual clauses in terms of generating construction waste. The AHP hierarchy has three levels: i.e. 1) Level 1 - potential of contractual clauses on generating construction waste was set as the goal; 2) Level 2 - eight categories of con- 
Table 1. Eight categories of potential contractual clauses

\begin{tabular}{|c|c|c|}
\hline No. & Category & Sample clauses \\
\hline 1 & Quality & $\begin{array}{l}\text { a) Should any dispute arise as to quality or fitness of product, decision rests strictly with } \\
\text { consultant based upon requirements of contract documents. } \\
\text { b) Replace materials of less than specified quality or as designated by architect and relocate } \\
\text { work incorrectly installed as determined by architect. }\end{array}$ \\
\hline 2 & Substitution & $\begin{array}{l}\text { There is no obligation on the part of the consultant or owner to accept proposed } \\
\text { substitutions. Acceptance of proposed substitutions by owners does not relieve the } \\
\text { contractor's responsibility under the contract. }\end{array}$ \\
\hline 3 & Workmanship & $\begin{array}{l}\text { Decisions as to quality or fitness of workmanship in case of dispute rest with the consultant, } \\
\text { whose decision is final. }\end{array}$ \\
\hline 4 & Geotechnical report & $\begin{array}{l}\text { The report, by its nature, cannot reveal all conditions that exist or can occur on the site. } \\
\text { Should sub surface conditions be found to vary substantially from those indicated in the soil } \\
\text { report, changes in the design and construction of foundations will be made accordingly with } \\
\text { resulting credits or expenditures accruing to the owner. }\end{array}$ \\
\hline 5 & $\begin{array}{l}\text { Submittals, Shop } \\
\text { drawings }\end{array}$ & $\begin{array}{l}\text { a) Consultant's review does not relieve the contractor of his responsibility for accuracy of } \\
\text { shop drawings. This review of the shop drawings shall not, in any way, relieve the contractor } \\
\text { from complying with all requirements of the contract documents. } \\
\text { b) Field verify all building and site dimensions prior to any fabrication and installation of } \\
\text { equipment or materials. No contract revisions will be considered for failure to verify these } \\
\text { dimensions on site. } \\
\text { c) Any review of shop drawings is for the sole purpose of ascertaining conformance with the } \\
\text { general design concept. This review shall not mean approval of detail design inherent in the } \\
\text { shop drawings, responsibility for which shall remain with the contractor submitting same and } \\
\text { as such review shall not relieve the contractor of responsibility for errors or omissions in the } \\
\text { shop drawing or of responsibility for meeting all requirements of the contract documents. } \\
\text { The contractor is responsible for dimensions to be confirmed and correlated at the job } \\
\text { site, for information that pertains solely to the fabrication processes or to techniques of } \\
\text { construction and installation and for coordination of the work of all sub trades. }\end{array}$ \\
\hline
\end{tabular}

a) Field service by the consultant or his representative does not in any way relieve the contractor of his responsibility to carry out the work per the contract document and contract drawings.

b) Contractors work will be inspected periodically by the Engineer solely for the purpose of determining general quality of work, and not for other purpose. Guidance will be offered to the contractor in interpretation of plans and specifications to assist them to carry out work.

6 Field quality control, Inspections and directives given to contractor does not relieve contractor and his agent, Inspection servants and employee of their responsibility to erect and install work in its parts in a safe and workmanlike manner, and in accordance with the plans and specifications, nor impose upon the Engineer any responsibility to supervise or oversee erection or installation of any work.

c) The location, arrangement and connection of equipment and materials as shown on the drawings represent a close approximation to the intent and requirement of the work. The right is reserved by the consultant to make responsible changes required to accommodate conditions arising during the progress of the work, at no extra cost to the owner.

\begin{tabular}{lll}
\hline 7 & Shop finish & Unfinished work will be listed as deficiencies. \\
\hline 8 & $\begin{array}{l}\text { Temporary or trial } \\
\text { usage, testing }\end{array}$ & $\begin{array}{l}\text { It is agreed and understood, that no claim for damage will be made for any injury or } \\
\text { breakage to any part or parts of above due to aforementioned tests, whether caused by } \\
\text { weakness or inaccuracy of parts, or by defective materials or workmanship of any kind } \\
\text { whatsoever. Supply all labour and equipment for such tests. }\end{array}$ \\
\hline
\end{tabular}

tractual clauses were defined as multiple criteria; and 3) Level 3 - two alternatives were defined as potential to generate waste (the eight categories have positive influence on creating construction waste) and no waste (the eight categories do not have positive influence on creating construction waste).

Table 3 shows seven point intensity scale used for pairwise comparison of criteria in AHP/group decision method. Although Saaty (1990) has used 1-9 scale, this research used 1 to 7 scale instead of 1 to 9 scale to simplify the ranking procedure. This strategy helped the respondents to have less cognitive burden, when they answered the survey. Survey participants used a 7 point scale to compare the contractual clause categories, where 1 and 7 represented extremely more important categories, when compared to one another, and 4 represents equally important category. These ratings have been converted to the seven point intensity scale for AHP/ group decision method. Ex: Rating 1 and 7 in the questionnaire is equivalent to 7 in the seven point intensity scale used in AHP/group decision method.

In AHP, pairwise comparison matrix (PCM) for eight criteria $C_{i j}$ is defined as: 
Table 2. Demographic information of the participants whose answers passed the consistency

\begin{tabular}{lll}
\hline \multicolumn{1}{c}{ Factor } & \multicolumn{1}{c}{ Number } \\
\hline \multirow{4}{*}{ Type of construction } & Residential & $: 3$ \\
& Industrial & $: 4$ \\
& Heavy highway & $: 12$ \\
& Institutional (other) :7 & $: 9$ \\
\hline & Project Mangers & $: 12$ \\
& Site Superintendent & $: 1$ \\
& Construction Manager & $: 2$ \\
& Operations Manager & $: 2$ \\
& Development Manager & $: 1$ \\
& Project Coordinator & $: 3$ \\
& Director & $: 1$ \\
& General Manager & $: 1$ \\
Job title & Architect & $: 1$ \\
& Structural Engineer & $: 2$ \\
& Division Manager & $: 1$ \\
& Sustainable Manager & $: 1$ \\
& Environmental Manager & $: 1$ \\
& Field Engineer & $: 1$ \\
& Access Planner & $: 1$ \\
\hline Range of working & 8 years to 45 years with an average \\
experience in & of 25 years. \\
\hline & \\
\hline
\end{tabular}

$$
C_{i j}=\left(\begin{array}{llllllll}
C_{11} & C_{12} & C_{13} & C_{14} & C_{15} & C_{16} & C_{17} & C_{18} \\
C_{21} & C_{22} & C_{23} & C_{24} & C_{25} & C_{26} & C_{26} & C_{27} \\
C_{31} & C_{32} & C_{33} & C_{34} & C_{35} & C_{36} & C_{37} & C_{38} \\
C_{41} & C_{42} & C_{43} & C_{44} & C_{45} & C_{46} & C_{47} & C_{48} \\
C_{51} & C_{52} & C_{53} & C_{54} & C_{55} & C_{56} & C_{57} & C_{58} \\
C_{61} & C_{62} & C_{63} & C_{64} & C_{65} & C_{66} & C_{67} & C_{68} \\
C_{71} & C_{72} & C_{73} & C_{74} & C_{75} & C_{76} & C_{77} & C_{78} \\
C_{81} & C_{82} & C_{83} & C_{84} & C_{85} & C_{86} & C_{87} & C_{88}
\end{array}\right) .
$$

Equations (2a) and (2b) represents $C_{i j}$ as:

$$
C_{i j}=\frac{\sum_{k=1}^{n} s_{k}}{n},
$$

where: $i \neq j ; S_{k}=$ weight calculated from a single participant (whose answer passed the consistency test) of the expert opinion survey; and $n=$ total no. of participants whose data with the required consistency (from the questionnaire survey).

$$
C_{i j}=1,
$$

where $i=j$.

Equation (3) shows normalized weights of PCM $(W)$ :

$$
W=\left(\begin{array}{l}
w_{1} \\
w_{2} \\
w_{3} \\
w_{4} \\
w_{5} \\
w_{6} \\
w_{7} \\
w_{8}
\end{array}\right)
$$

Equation (4) shows one element of $W\left(W_{i}\right)$ as:

$$
W_{i}=\frac{\left(C_{i 1} \times C_{i 2} \times \cdots \cdots C_{i 8}\right)^{1 / 8}}{\sum_{i=1}^{8}\left(C_{i 1} \times C_{i 2} \times \cdots \cdots C_{i 8}\right)^{1 / 8}} .
$$

Then two alternatives should be evaluated against each and every criterion. Eqn (5) shows the illustrated example for criteria no. 1 (category 1):

$$
\begin{array}{lll} 
& \text { Waste } & \text { No Waste } \\
\text { Waste } & \mathrm{A}_{11} & \mathrm{~A}_{12} \\
\text { No Waste } & \mathrm{A}_{21} & \mathrm{~A}_{22} .
\end{array}
$$

Equations (6a) and (6b) represents $A_{i j}$ as:

$$
A_{i j}=\frac{\sum_{k=1}^{n} T_{k}}{n},
$$

where $i \neq j$.

$$
A_{i j}=1
$$

where $i=j$.

$T_{k}=$ weight calculated from a single participant (whose answer passed the consistency test) of the expert opinion survey, $n=$ total no. of participants whose data with the required consistency (from the questionnaire survey). Then Eqn (7) shows the matrix for category 1(M1), and Eqns (8a) and (8b) shows its elements.

$$
\begin{gathered}
M 1=\left(\begin{array}{c}
A_{1} \\
A_{1}^{*}
\end{array}\right) ; \\
A_{1}=\frac{\left(A_{11} \times A_{12}\right)^{1 / 2}}{\left(A_{11} \times A_{12}\right)^{1 / 2}+\left(A_{21} \times A_{22}\right)^{1 / 2}} ; \\
A_{1}^{*}=\frac{\left(A_{21} \times A_{22}\right)^{1 / 2}}{\left(A_{11} \times A_{12}\right)^{1 / 2}+\left(A_{21} \times A_{22}\right)^{1 / 2}} .
\end{gathered}
$$

Thus Matrix A (Eqn (9)) contains the matrices (M1 to M9) of eight criteria (all clauses categories), and it represents relative contribution between two alternatives towards the eight criteria. 


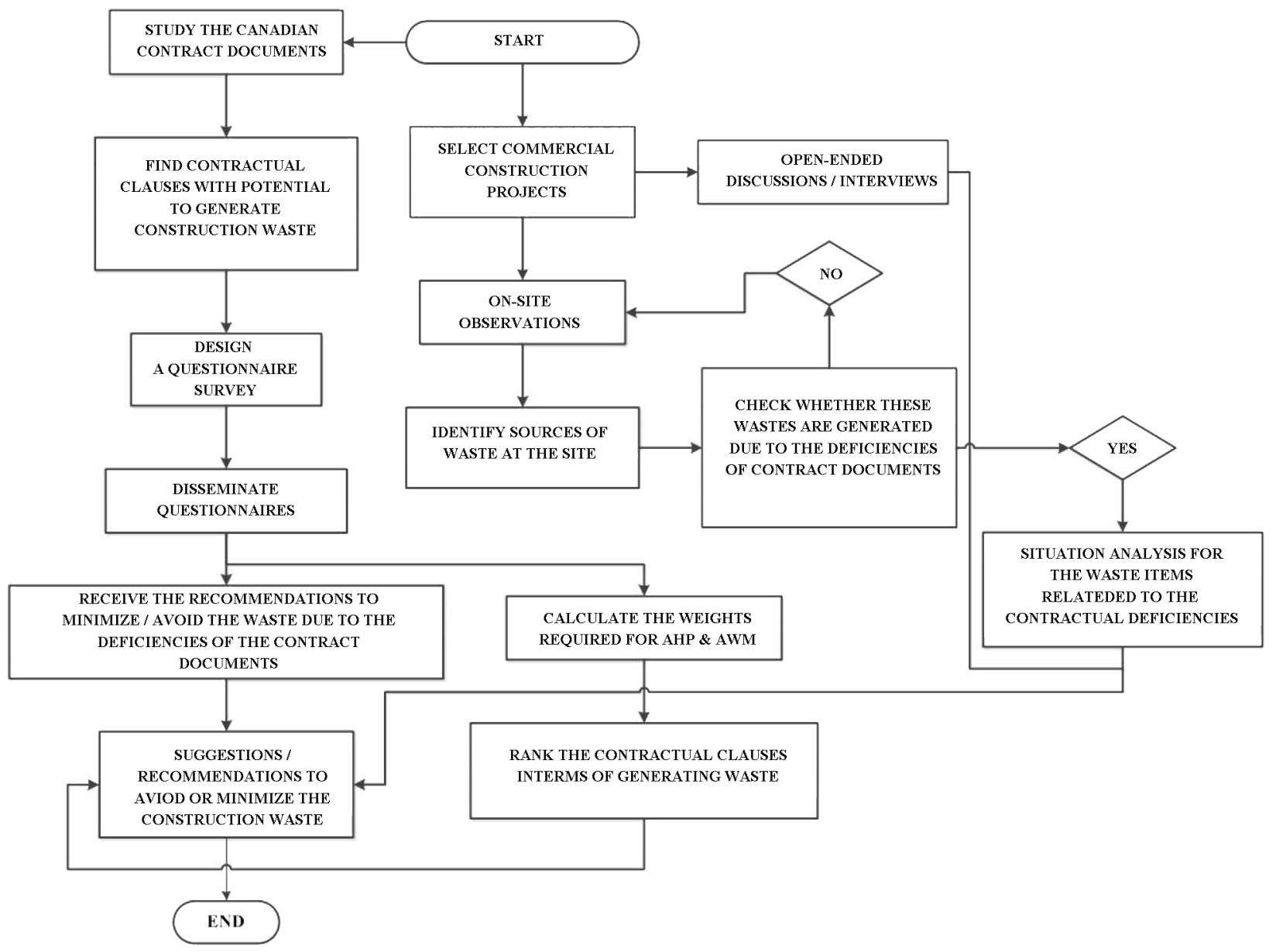

Fig. 1. Theoretical framework

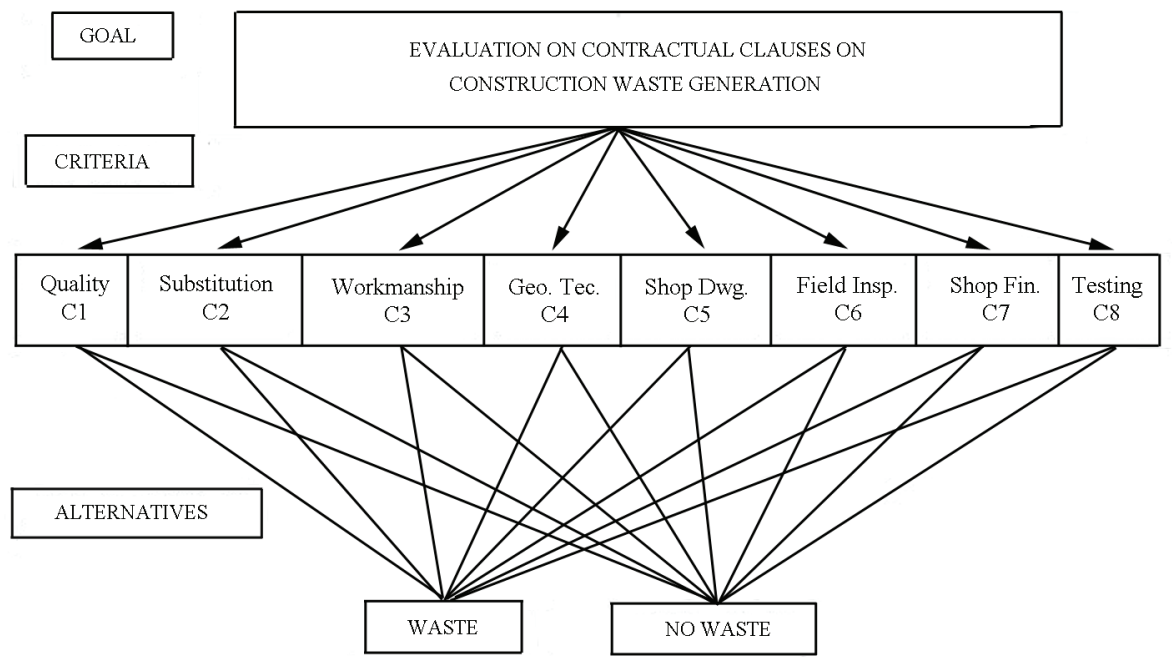

Fig. 2. Hierarchical structure of AHP 
Table 3. Relation between rating scale and equivalent seven point intensity scale of pairwise comparison matrix

\begin{tabular}{llllllll}
\hline Rating in the questionnaire & 1 & 2 & 3 & 4 & 5 & 6 & 7 \\
\hline Seven point intensity scale & 7 & 5 & 3 & 1 & 3 & 5 & 7 \\
\hline
\end{tabular}

$$
A=\left(\begin{array}{cccccccc}
A_{1} & A_{2} & A_{3} & A_{4} & A_{5} & A_{6} & A_{7} & A_{8} \\
A_{1}^{*} & A_{2}^{*} & A_{3}^{*} & A_{4}^{*} & A_{5}^{*} & A_{6}^{*} & A_{7}^{*} & A_{8}^{*}
\end{array}\right)
$$

Risk ratio $=$

$$
\left(\begin{array}{cccccccc}
A_{1} & A_{2} & A_{3} & A_{4} & A_{5} & A_{6} & A_{7} & A_{8} \\
A_{1}^{*} & A_{2}^{*} & A_{3}^{*} & A_{4}^{*} & A_{5}^{*} & A_{6}^{*} & A_{7}^{*} & A_{8}^{*}
\end{array}\right) \times\left(\begin{array}{c}
w_{1} \\
w_{2} \\
w_{3} \\
w_{4} \\
w_{5} \\
w_{6} \\
w_{7} \\
w_{8}
\end{array}\right) .
$$

In Eqn (10), Multiplication of $W$ (Eqn 3) and A (Eqn 9) gives the risk ratio between potential to generate Waste and No Waste. The risk ratio between Waste/No Waste gives an indication of overall tendency of generating construction waste with respect to all the clauses. In addition, it is possible to rank the clause categories by considering the normalized form of PCM $(W)$, since PCM can be considered as a group decision method.

\subsection{Attribute weighing method (AWM) to rank the contractual clauses}

The contractual clauses categories (shown in Table 1) were ranked as per the average values of the questionnaire survey results. As per Stillwell et al. (1981), attribute weights can be calculated, and clauses can be ranked. These ranks can be taken as R1, R2, R3, R4, R5, R6, $\mathrm{R} 7$, and R8; and $\mathrm{n}$ can be taken as number of categories. Then weights $(W)$ can be calculated as per Eqn (11) (rank reciprocal weights):

$$
W=\frac{1 / R_{i}}{\sum_{k=1}^{n} 1 / R_{k}} .
$$

\section{Results}

Results of the questionnaire surveys, field observations, and interviews are presented in the following section.

\subsection{Questionnaire survey analysis with group decision method (pairwise comparison)}

The eight categories of contractual clauses indicated in Table 1 were defined as multiple criteria. These eight categories were included in Table 4, and they were arranged in a pairwise manner. These pairs were compared by the survey participants. The summarized results of pairwise comparisons of questionnaire surveys are shown in Table 4. The values of Table 4 were calculated by taking the average of all the responses that passed the consistency test, individually. It represents the relative importance of contractual clauses in terms of generating construction waste. Therefore, these average values directly provide the input values for the elements of the PCM. For example, the value 4.13 in the first raw of Table 4 is the average value for all pairwise comparisons between quality vs. substitution taken from all the questionnaires that individually passed the consistency test (i.e. quality is 4.13 times more important than substitution in terms of generating construction waste).

Notations $\mathrm{C} 1$ to $\mathrm{C} 8$ represent the clauses categories (Ref. Table 5).The Consistency ratio (CR) of PCM was 0.0603 (CR < 0.1). As per Saaty (1990), PCM has the required consistency. By checking the consistency, internal consistency reliability and inter-rater or inter-observer reliability (in terms of reliability) can be achieved (Trochim 2000). Table 7 shows normalized weights of PCM and ranking of clause categories. Normalized weights of PCM, W (Eqn (3)) were determined as per Eqn (4).

Thus, final ranking among eight clause categories can be illustrated as $\mathbf{C 1}>\mathbf{C 3}>\mathbf{C 6}>\mathbf{C 4}>\mathbf{C 5}>\mathbf{C 2}>$ C7 $>$ C8. As per the analysis, Quality clauses have the highest potential/risk to generate construction waste. The second and third priorities are workmanship clauses and field quality \& inspection clauses respectively. Quality, workmanship, and field quality\& inspection clauses have $27.18 \%, 25.54 \%$, and, $9.86 \%$ of weights respectively. Geotechnical report, substitution clauses, and shop drawings contain intermediate level of risks; and shop finish and testing account clauses have a low risk level.

\subsection{Questionnaire survey analysis with AHP}

Matrix A (Eqn (9)) contains the matrices of eight criteria (all clause categories), and it was calculated as per Eqns (5), (6a), (6b), (7), (8a), (8b), and (9).

As per Eqn (10), the ratio between Waste and No Waste (Risk ratio) is:

$$
\begin{aligned}
& =1.58 / 0.32 ; \\
& =4.92
\end{aligned}
$$

AHP sensitivity analysis was performed to observe the changes in the relative weights (of the criteria), which influence the final risk ratio. A sample calculation is shown in Table 6, and the relative weight of the each criterion was increased by $30 \%$ each time. The sensitivity analysis shows that changes to the three contractual clause categories with highest potential/risk to generate construction waste, has an upward movement. Changes to the other six contractual clause categories with lower 
Table 4. Pairwise comparison for clause categories

\begin{tabular}{|c|c|c|}
\hline Symbol & $\begin{array}{c}\text { Pairwise comparison } \\
\text { category }\end{array}$ & Average value \\
\hline $\mathrm{C} 12$ & Quality vs. Substitution & 4.13 \\
\hline $\mathrm{C} 13$ & Quality vs. Workmanship & 1.36 \\
\hline $\mathrm{C} 14$ & Quality vs. Geotechnical report & 4.39 \\
\hline $\mathrm{C} 15$ & Quality vs. Submittals/Shop drawings Clauses & 3.84 \\
\hline $\mathrm{C} 16$ & Quality vs. Field quality control/Inspection & 1.68 \\
\hline $\mathrm{C} 17$ & Quality vs. Shop finish & 3.92 \\
\hline $\mathrm{C} 18$ & Quality vs. Temporary or trial usage/testing & 3.79 \\
\hline $\mathrm{C} 23$ & Substitution vs. Workmanship & 0.43 \\
\hline $\mathrm{C} 24$ & Substitution vs. Geotechnical report & 1.46 \\
\hline $\mathrm{C} 25$ & Substitution vs. Submittals/Shop drawings & 0.47 \\
\hline $\mathrm{C} 26$ & Substitution vs. Field quality control/Inspection & 1.56 \\
\hline $\mathrm{C} 27$ & Substitution vs. Shop finish & 2.07 \\
\hline $\mathrm{C} 28$ & Substitution vs. Temporary or trial usage/testing & 1.49 \\
\hline $\mathrm{C} 34$ & Workmanship vs. Geotechnical report & 4.28 \\
\hline $\mathrm{C} 35$ & Workmanship vs. Submittals/Shop drawings & 4.02 \\
\hline $\mathrm{C} 36$ & Workmanship vs. Field quality control/Inspection & 2.90 \\
\hline $\mathrm{C} 37$ & Workmanship vs. Shop finish & 3.98 \\
\hline $\mathrm{C} 38$ & Workmanship vs. Temporary or trial usage/testing & 4.18 \\
\hline $\mathrm{C} 45$ & Geotechnical report vs. Submittals/Shop drawings & 2.15 \\
\hline $\mathrm{C} 46$ & Geotechnical report vs. Field quality control/Inspection & 1.46 \\
\hline $\mathrm{C} 47$ & Geotechnical report vs. Shop finish & 2.20 \\
\hline $\mathrm{C} 48$ & Geotechnical report vs. Temporary or trial usage/testing & 2.14 \\
\hline C56 & Submittals/Shop drawings vs. Field quality control/Inspection & 1.83 \\
\hline $\mathrm{C} 57$ & Submittals/Shop drawings vs. Shop finish & 2.48 \\
\hline C58 & Submittals/Shop drawings vs. Temporary or trial usage/testing & 1.49 \\
\hline C67 & Field quality control/Inspection vs. Shop finish & 3.69 \\
\hline C68 & Field quality control/Inspection vs. Temporary or trial usage/testing & 3.88 \\
\hline $\mathrm{C} 78$ & Shop finish vs. Temporary or trial usage/testing & 1.52 \\
\hline
\end{tabular}

Table 5. Ranking of clause categories in terms of potential/influence on generating construction waste

\begin{tabular}{llc}
\hline Category & \multicolumn{1}{c}{ Clause category } & $\begin{array}{c}\text { Average rating over generating } \\
\text { construction waste }\end{array}$ \\
\hline C1 & Quality & 5.81 \\
\hline C2 & Substitution & 4.06 \\
\hline C3 & Workmanship & 6.23 \\
\hline C4 & Geotechnical report & 3.58 \\
\hline C5 & Submittals/Shop drawings & 3.58 \\
\hline C6 & Field quality control/Inspection & 5.26 \\
\hline C7 & Shop finish & 2.58 \\
\hline C8 & Temporary or trial usage/testing & 4.65 \\
\hline
\end{tabular}


Table 6. AHP sensitivity analysis

\begin{tabular}{llcl}
\hline Category & & Risk ratio & Change \\
\hline Quality & C1 & 5.0032 & Upward \\
\hline Substitution & C2 & 4.8804 & Downward \\
\hline Workmanship & C3 & 4.9840 & Upward \\
\hline Geotechnical report & C4 & 4.9186 & Downward \\
\hline Shop drawings & C5 & 4.8979 & Downward \\
\hline Field quality \& Inspection & C6 & 4.9319 & Upward \\
\hline Shop finish & C7 & 4.8793 & Downward \\
\hline Temporary trial \& Testing & C8 & 4.8770 & Downward
\end{tabular}

Table 7. Normalized weights of PCM and Ranking of clause category

\begin{tabular}{llcrc}
\hline \multicolumn{1}{c}{ Category } & & Normalized weights & Weights $\%$ & Rank \\
\hline Quality & C1 & 0.271759299 & $27.18 \%$ & 1 \\
\hline Substitution & C2 & 0.089959277 & $9.00 \%$ & 6 \\
\hline Workmanship & C3 & 0.255382627 & $25.54 \%$ & 2 \\
\hline Geotechnical report & C4 & 0.095276561 & $9.53 \%$ & 4 \\
\hline Shop drawings & C5 & 0.092826937 & $9.28 \%$ & 5 \\
\hline Field quality\& Inspection & C6 & 0.098565112 & $9.86 \%$ & 3 \\
\hline Shop finish & C7 & 0.048175232 & $4.82 \%$ & 7 \\
\hline Temporary trial \& Testing & C8 & 0.048054955 & $4.81 \%$ & 8 \\
\hline
\end{tabular}

Table 8. Ranking of clause categories sorted weights in the order of their magnitudes

\begin{tabular}{ccccc}
\hline Clauses category & $\begin{array}{c}\text { Rank (used } \\
\text { survey data) }\end{array}$ & 1/Ri & $\begin{array}{c}\text { Weights } \\
\text { (as per equation 3.11) }\end{array}$ & $\begin{array}{c}\text { Percentages } \\
\%\end{array}$ \\
\hline C3 & 1 & 1.00 & 0.36578013 & $36.57 \%$ \\
C1 & 2 & 0.50 & 0.18289006 & $18.29 \%$ \\
\hline C6 & 3 & 0.33 & 0.12192671 & $12.19 \%$ \\
\hline C8 & 4 & 0.25 & 0.09144503 & $9.14 \%$ \\
\hline C2 & 5 & 0.20 & 0.07315602 & $7.32 \%$ \\
\hline C4 & 6 & 0.15 & 0.05627386 & $5.63 \%$ \\
\hline C5 & 7 & 0.15 & 0.05627386 & $5.63 \%$ \\
\hline C7 & 8 & 0.14 & 0.05225430 & $5.23 \%$ \\
\hline Total & & & 1.00 & $100 \%$ \\
\hline
\end{tabular}

potential/risk to generate construction waste, has a downward movement.

\subsection{Questionnaire survey analysis with AWM}

The eight categories were individually ranked.

The questionnaire survey data of Table 5 has been used to rank the contractual clause categories, considering the average ranking of each category. Table 8 illustrates the final results.

Thus, final ranking among eight clauses can be shown as $\mathbf{C 3}>\mathbf{C 1}>\mathbf{C 6}>\mathbf{C 8}>\mathrm{C2}>\mathrm{C4}$, C5 $>$ C7 . Workmanship clauses have the highest potential/risk to generate construction waste. The second and third pri- orities are quality clauses and field quality \& inspection clauses, respectively. Quality, workmanship, and field quality \& inspection clauses have $18.29 \%, 36.57 \%$, and $12.19 \%$ of weights respectively. Temporary trial and testing, and substitution clauses contain intermediate risk levels. Shop drawings, shop finish, and geotechnical report account for low level of risks.

\section{Discussion}

This study critically analysed the most common contract documents in Canada for its potential to generate construction waste. The research project discussed in this paper provides valuable contributions to the body of 
knowledge by identifying and prioritizing the most influencing contract clauses, which have potentials to create construction waste. During an extensive literature review, authors did not locate any published studies (or statistics) in technical journals or reputed web sites, which examined the influence of contractual clauses/agreements in generating construction waste, in Canada or any other part of the world. In addition, this study concluded key focus areas that need immediate attention of construction managers and legal professionals. Further, this study might motivate the construction industry to create fair contractual documents which have less potential to create rework and waste. In addition, this paper demonstrated an application of the decision making theories (AHP and group decision making method and AWM), in the contract administration area, to quantify professionals' views.

Ranking several factors in a given time may create a heavy cognitive burden on the decision maker. Thus, a method by which a complete ranking can be obtained, from a set of pairwise judgement, is the preferred approach. Therefore, the group decision method is recommended over AWM. On top of that, the group decision method offers a valuable tool for testing the consistency of the evaluation measures. Judgments can be affected by availability heuristics and social influences of the decision maker. Taking a large number of samples, bias can be minimized; however, it can't be completely avoided.

Despite the method of analysis, the top 3 clauses categories, which influence construction waste generation, remained the same. It is interesting to note that AHP sensitivity analysis follows the exact pattern shown in the group decision method (done by pairwise comparison). There is no impact on the scale for the results between two methods.

\section{Limitations and future research}

This research reviewed and analysed most influential categories of contractual clauses, which have potentials to create construction waste; however, there are many other minor areas which may have a cumulative impact on waste generation. In addition, this research is limited to the Canadian contract documents. A wide range of contractual models and standard contracts are used in the world. Contract documents can be changed from region to region, country to country, and even province to province within the same country. The views and analysis discussed in this paper are strictly limited to the analysed contract documents. It is suggested to conduct further research to analyse contractual clauses in different regions of the world to identify global attention areas to reduce construction waste. Such research projects may reveal contractual conflicts in multi-national construction projects, which ultimately create rework and construction waste. Further research is also recommended to identify fair risk allocation in contract documents among contractors, owners, and other key project stakeholders. Such approach may positively influence to reduce con- struction rework and waste. Finally, this research project revealed the importance of collaborative studies among legal and construction professionals. Such synergy in future research may help to create more practical and sustainable construction contract documents.

\section{Conclusions and recommendations}

As per the analysed expert opinions, with group decision method and AWM, it can be concluded that the following three contractual clause categories have the maximum potential to create construction waste:

1) Category 1 (Quality);

2) Category 3 (Workmanship);

3) Category 6 (Field quality control and Inspection).

Thus, priority should be given to amend these high potential/risk contractual clauses in standard Canadian construction contract documents. Contractual clause rewriting is beyond the objectives of this paper.

Poor quality assurance process for completed designs is evident in construction projects. It causes design errors, omissions, and incompatibilities in the final drawings. The completed designs should be reviewed by an expert design team (preferably, a third party) to identify any design errors, omissions, constructability issues, and incompatibilities. Such specific requirement may be included in the standard contractual agreements.

In general, errors and discrepancies in the contract documentation are assumed to be identified by the contractor/subcontractors, regardless of the party that made the contract documents. This practice tends to create rework and waste. The party that prepared the contract documents should be responsible for the accuracy and quality of the documents, and that party should warrant the content of documents to provide accurate information. The consultant's working time on a project is generally depends on fee allocations. This practice may impact the quality of the contract documentation and quality of field inspections.

In addition, ambiguous communication and vague wordings in contract documents create rework/waste. Contract documents should be written in crisp technical language (avoid vague language) by explaining the work acceptance and rejection procedure. It prevents contractual agreements to fall into grey areas, and eliminates confusions and conflicts.

Authors' field observations noted lack of coordination among designers and subcontractors. As a result, construction waste and rework was generated. It is recommended to include a clause in standard contract documents to enforce an obligatory requirement, for coordination among all designers and subcontractors, to avoid conflicting situations. Such coordination should be happen, at least, at major project milestones (e.g. at the end of individual design processes, when issuing the drawings for client's approval, when issuing drawings for building permits, when issuing drawings for construction, when producing shop drawings, and when approving shop drawings). 
Moreover, exculpatory contractual clauses that are written for the shop drawing review process should be reevaluated. It may be done by enforcing equal obligations between the main project parties (i.e. designers, main contractors, and construction managers) who review/approve the shop drawings, and the parties that produce shop drawings (i.e. subcontractors, main contractors). The consultants (engineer/architect) or owner should take the responsibility of what they have reviewed and approved, to minimize potential future changes.

Insufficient and irresponsible supervisions by consultants, under the current contract agreements, create rework and waste (e.g. clause category no. 6). A joint field inspection/testing procedure may be implemented with the contractor and the consultant, at pre-identified intervals, to accept or reject the completed works. A fair distribution of responsibilities of quality inspections among the contractor and consultant is needed to minimize construction waste.

Another noted factor on waste generation is the limited knowledge on constructability during the project design stage. Design engineers should consult all potential project stakeholders (i.e. contractors) for the decisions related to constructability. Such a need should be emphasized in the contract agreements.

Fast-track projects generally start before the completion of designs and contract documents (e.g. construction drawings, contractual agreements, technical specifications). Most construction processes in the "fasttrack" approach commence even before the completion of the necessary designs. It is recommended to initiate a contractual obligation, which prevents the start of the construction process, until all essential designs and other contract documents are finalized.

In addition, after completing the final design, a model (computer or physical) may be used to visualize the structure. A client, who does not have a technical background, may not be able to understand and interpret technical drawings and specifications in the standard format. A visual model may help to ensure that the designs have fulfilled all stakeholders' expectations. It is worthy to impose an obligatory requirement to provide such a visualization aid prior to the project construction phase.

At present, the general practice is to copy and paste design details and specification from one contract document to another. This practice has high chances to repeat unrelated design components in new projects. Contract documentation and specifications should always be tailored for specific project requirements.

\section{Acknowledgements}

Authors would like to acknowledge following associations and individuals whose contributions have significantly shaped the content of this paper: Mr Phil Long (Senior Project Manager, Stuart Olson Dominion Construction, Canada), Mr Jason Mallhi (Senior Project Coordinator, Stuart Olson Dominion Construction, Canada), Mr David
Roche, (Development Manager, UBC Properties Trust), Mr Lorne Antle (Project Manager, UBC Properties Trust), Mr Paul Krzywicki (Project Manager, Yellowridge Construction Ltd., Canada). Authors also acknowledge the financial contributions of the National Science and Engineering Research Council of Canada.

\section{References}

Ahzahar, N.; Karim, N. A.; Hassan, S. H.; Eman, J. 2011. A study of contribution factors to building failures and defects in construction industry, in Proceedings of the $2^{\text {nd }}$ International Building Control Conference, 11-12 July 2011, Penang, Malaysia, 249-255.

Bosche, R. V. 1978. Identifying construction claims, in Proceedings of the Transactions of the American Association of Cost Engineers, 9-12 July 1978, San Francisco, California, 320-329.

Bossink, B. A. G.; Brouwers, H. J. H. 1996. Construction waste: quantification and source evaluation, Journal of Construction Engineering and Management 122(1): 55-60.

http://dx.doi.org/10.1061/(ASCE)0733-9364(1996)122:1(55)

Canadian Construction Document committee. 2012. CCDC contract forms [online], [cited 11 April 2012]. Available from Internet: http://www.ccdc.org/downloads/index.html

Doloi, H.; Sawhney, A.; Iyer, K. C.; Rentala, S. 2011. Analyzing factors affecting delays in Indian construction projects, International Journal of Project Management 30: 479489. http://dx.doi.org/10.1016/j.ijproman.2011.10.004

Eggleston, B. 2004. Limited damages and extensions of time in construction contracts. $2^{\text {nd }}$ ed. Oxford: Blackwell. $337 \mathrm{p}$.

Hwang, B. G.; Thomas, S. R.; Haas, C. T.; Caldas, C. H. 2009. Measuring the impact of rework on construction cost performance, Journal of Construction Engineering and Management 135(3): 187-198.

http://dx.doi.org/10.1061/(ASCE)0733-9364(2009)135:3(187)

Jergeas, G.; Hartman, F. T. 1996. A contract clause for allocating risks, in Proceedings of the $40^{\text {th }}$ Annual Meeting of Transactions of the American Association of Cost Engineers, 23-26 June 1996, Vancouver, 11-13.

Li, Y.; Taylor, T. R. B. 2011. The impact of design rework on construction project performance, in Proceedings of the $29^{\text {th }}$ International Conference of the System Dynamics Society, 25-29 July 2011, Washington, DC, 1267-1272.

Loosemore, M. 1999. Responsibility, power and construction conflict, Construction Management Economics 17(6): 699-709. http://dx.doi.org/10.1080/014461999371042

Love, P. E. D.; Edwards, D. J.; Watson, H.; Davis, P. 2010. Rework in civil infrastructure projects: determination of cost predictors, Journal of Construction Engineering and Management 136(3): 275-282.

http://dx.doi.org/10.1061/(ASCE)CO.1943-7862.0000136

Love, P. E. D.; Edwards, D. J.; Irani, Z.; Walker, D. H. T. 2009. Project pathogens: the anatomy of omission errors in construction and resource engineering project, IEEE Transactions on Engineering Management 56(3): 425-435. http://dx.doi.org/10.1109/TEM.2008.927774

Love, P. E. D.; Edwards, D. J.; Irani, Z. 2008. Forensic project management: an exploratory examination of the causal behavior of design-induced rework, IEEE Transactions on Engineering Management 55(2): 234-247. http://dx.doi.org/10.1109/TEM.2008.919677

Love, P. E. D.; Sohal, A. S. 2003. Capturing rework cost in projects, Managerial Auditing Journal 18(4): 329-339. http://dx.doi.org/10.1108/02686900310474343 
Love, P. E. D. 2002. Influence of project type and procurement method on rework Costs in Building Construction Projects, Journal of Construction Engineering and Management 128(1): 18-27.

http://dx.doi.org/10.1061/(ASCE)0733-9364(2002)128:1(18)

Lu, W.; Yuan, H. 2011. A framework for understanding waste management studies in construction, Waste Management 31(6): 1252-1260. http://dx.doi.org/10.1016/j.wasman.2011.01.018

Lu, W.; Yuan, H.; Li; J. R.; Hao, J. L.; Mi, X. M.; Ding, Z. K. 2011. An empirical investigation of construction and demolition waste generation rates in Shenzhen city, South China, Waste Management 31(4): 680-687. http://dx.doi.org/10.1016/j.wasman.2010.12.004

Lu, W.; Yuan, H. 2010. Exploring critical success factors for waste management in construction projects of China, Resources, Conservation \& Recycling 55(2): 201-208. http://dx.doi.org/10.1016/j.resconrec.2010.09.010

Mendis, D.; Hewage, K. N. 2011. Contractual obligations analysis to enhance construction waste management, in Proceedings of $3^{\text {rd }}$ International/9 $9^{\text {th }}$ Construction Specialty Conference, 14-17 June 2011, Ottawa, Ontario, Canada, 2040-2049.

Moazzami, M.; Dehghan, R.; Ruwanpura, J. Y. 2011. Contractual risks in fast-track projects, in Proceedings of the Twelfth East Asia-Pacific Conference on Structural Engineering and Construction, 26-28 January 2011, Hong Kong, 2552-2557.

Powell-Smith, V.; Sims, J. 1990. Contract documentation for contractors. Oxford: BSP Professional Books. 350 p.
Riches, J. L.; Dancaster, C. 2004. Construction adjudication. $2^{\text {nd }}$ ed. Cornwall: Blackwell. 424 p.

Fayek, R. A.; Dissanayake, M.; Campero, O. 2003. Measuring and classifying construction field rework: a pilot study. Construction Owners Association of Alberta, Alberta [online], [cited 30 April 2012]. Available from Internet: http://www.Construction.ualberta.ca/ rework/Rework Pilot Study 2003 Executive Summary.pdf

Saaty, T. L. 1990. How to make a decision: the analytic hierarchy process, European Journal of Operational Research 28(1): 9-26. http://dx.doi.org/10.1016/0377-2217(90)90057-I

Stillwell, W. G.; Seaver, D. A.; Edwards, E. 1981. A comparison of weight approximation techniques in multiattribute utility decision making, Organizational Behavior and Human Performance 28(1): 62-77.

http://dx.doi.org/10.1016/0030-5073(81)90015-5

The Canadian Construction Association. 1992. Waste management for the construction industry [online], [cited 10 December 2010]. Available from Internet: http://www. nrtee-trnee.com/eng/publications/waste-managementconstruction/waste-management-construction.pdf

Trochim, W. 2000. The research methods knowledge base. $2^{\text {nd }}$ ed. Cincinnati: Atomic Dog Publishing. 34 p.

Vidogah, W.; Ndekugri, I. 1997. Improving management of claims: contractors' perspective, Journal of Management in Engineering 13(5): 37-44

http://dx.doi.org/10.1061/(ASCE)0742-597X(1997)13:5(37).

\section{Appendix 1}

\section{Questionnaire}

Questionnaire Date: Number:

Note: All the information will be kept confidential and will not be disclosed to your company or any other persons. It will remain with the University of British Columbia.

\section{IMPACTS OF PROJECT CONTRACT DOCUMENTS ON REWORK AND WASTE GENERATION}

This document consists of two major sections:

1. Questionnaire (Appendix 1)

2. Contractual Clauses with Potentials to Generate Rework or Waste (Appendix 2)

1. Demographic Information (confidential):

1.1. Type of construction (Please select as appropriate):
a. Residential
b. Industrial
c. Commercial.
d. Infrastructure and heavy highway.
e. Other (specify)

1.2. Job title:

1.3. Years of working experience in construction:

\section{PART 1}

Please rank the potentials to generate Construction waste under each category of Contract clauses by using 8 point intensity scale. Use 1 to indicate the least potential and 8 to indicate the most potential.

Please refer the following example:

If you think "Quality" clauses (Category 1 in Appendix 2) are the most important among all clauses (all categories in Appendix 2) you should write " 8 " under column 3(the column which indicates the RANK). 


\section{PART 2}

Please evaluate the relative importance of Contractual Clauses stated in the Appendix 2 in terms of potential to generate Construction waste by filling column $\mathrm{C}$ in Table 3. Please use the guidance given in Table 2.

RAW 1: Quality vs. Substitution

If you think Contractual clauses related to "Quality" (Category 1 in Appendix 2) are more important than Contract clauses related to "Substitution" (Category 2 in Appendix 2) in terms of generating Construction waste, you should write " 2 " in column $\mathrm{C}$ of the Table 3.

\section{PART 3}

Open-ended questions for the last part of the questionnaire and interviews:

1. Have you noticed any other contractual clauses in your current/previous projects which have potential to generate construction waste?

2. Please state your suggestions to change or modify any contractual clauses to minimize construction waste generation.

3. Please mention your experience about the relationship between construction waste and deficiencies of contract documents/agreements etc.

4. Any other comments related to construction waste and contract documents/obligations.

Table 1. Ranking of categories in Appendix 2

\begin{tabular}{cl}
\hline Category & \multicolumn{1}{c}{ Description of clauses } \\
\hline 1 & Quality \\
\hline 2 & Substitution \\
\hline 3 & Workmanship \\
\hline 4 & Geotechnical report \\
\hline 5 & Submittals/Shop drawings \\
\hline 6 & Field quality control/Inspection \\
\hline 7 & Shop finish \\
\hline 8 & Temporary or trial usage/testing \\
\hline
\end{tabular}

Table 2. Comparison categories and their ratings

\begin{tabular}{lc}
\hline \multicolumn{1}{c}{ Description } & Ratings \\
\hline Column A is extremely more important than column B & 1 \\
\hline Column A is more important than column B & 2 \\
\hline Column A is moderately more important than column B & 3 \\
\hline Column A is equally important as column B & 4 \\
\hline Column B is moderately more important than column A & 5 \\
\hline Column B is more important than column A & 6 \\
\hline Column B is extremely more important than column A & 7 \\
\hline
\end{tabular}


Table 3. Comparison table

\begin{tabular}{|c|c|c|c|}
\hline Raw No. & Column A & Column B & Column C \\
\hline 1 & Quality & Substitution & \\
\hline 2 & Quality & Workmanship & \\
\hline 3 & Quality & Geotechnical report & \\
\hline 4 & Quality & Submittals/Shop drawings & \\
\hline 5 & Quality & Field quality control/Inspection & \\
\hline 6 & Quality & Shop finish & \\
\hline 7 & Quality & Temporary or trial usage/testing & \\
\hline 8 & Substitution & Workmanship & \\
\hline 9 & Substitution & Geotechnical report & \\
\hline 10 & Substitution & Submittals/Shop drawings & \\
\hline 11 & Substitution & Field quality control/Inspection & \\
\hline 12 & Substitution & Shop finish & \\
\hline 13 & Substitution & Temporary or trial usage/testing & \\
\hline 14 & Workmanship & Geotechnical report & \\
\hline 15 & Workmanship & Submittals/Shop drawings & \\
\hline 16 & Workmanship & Field quality control/Inspection & \\
\hline 17 & Workmanship & Shop finish & \\
\hline 18 & Workmanship & Temporary or trial usage/testing & \\
\hline 19 & Geotechnical report & Submittals/Shop drawings & \\
\hline 20 & Geotechnical report & Field quality control/Inspection & \\
\hline 21 & Geotechnical report & Shop finish & \\
\hline 22 & Geotechnical report & Temporary or trial usage/testing & \\
\hline 23 & Submittals/Shop drawings & Field quality control/Inspection & \\
\hline 24 & Submittals/Shop drawings & Shop finish & \\
\hline 25 & Submittals/Shop drawings & Temporary or trial usage/testing & \\
\hline 26 & Field quality control/Inspection & Shop finish & \\
\hline 27 & Field quality control/Inspection & Temporary or trial usage/testing & \\
\hline 28 & Shop finish & Temporary or trial usage/testing & \\
\hline
\end{tabular}

\section{Appendix 2}

\section{Contractual clauses with potentials to generate rework or waste}

The following contractual clauses with the potential to generate rework or waste were found by studying the contract documents of several construction projects.

\section{Category $1 /$ Quality}

I. Should any dispute arise as to quality or fitness of product, decision rests strictly with consultant based upon requirements of contract documents.

II. Replace materials less than specific quality or as designated by architect and relocate work incorrectly installed as determined by architect.

\section{Category 2/Substitution}

I. There is no obligation on the part of the consultant or owner to accept proposed substitutions. Acceptance of proposed substitutions by owners does not relieve the contractor's responsibility under the contract.

\section{Category 3/Workmanship}

I. Decisions as to quality or fitness of workmanship in case of dispute rest with consultant, whose decision is final.

\section{Category 4/Geotechnical report}

I. The report, by its nature, cannot reveal all conditions that exist or can occur on the site. Should sub surface conditions be found to vary substantially from those indicated in the soil report, changes in the design and construction of foundations will be made accordingly with resulting credits or expenditures accruing to the owner. 


\section{Category 5/Submittals, Shop drawings}

I. The consultant's review does not relieve the contractor of his responsibility for accuracy of shop drawings. This review of the shop drawings shall not, in any way, relieve the contractor from complying with all requirements of the contract documents.

II. Field verify all building and site dimensions prior to any fabrication and installation of equipment or materials. No contract revisions will be considered for failure to verify these dimensions on site.

III. Any review of shop drawings is for sole purpose of ascertaining conformance with the general design concept. This review shall not mean approval of detail design inherent in the shop drawings, responsibility for which shall remain with the contractor submitting same and as such review shall not relieve the contractor of responsibility for errors or omissions in the shop drawing or of responsibility for meeting all requirements of the contract documents. The contractor is responsible for dimensions to be confirmed and correlated at the job site, for information that pertains solely to the fabrication processes or to techniques of construction and installation, and for coordination of the work of all sub trades.

\section{Category 6/Field quality control, Inspection}

I. Field service by the consultant or his representative do not in any way relieve the contractor of his responsibility to carry out the work per the contract document and contract drawings.

II. Contractors work will be inspected periodically by the Engineer solely for the purpose of determining general quality of work, and not for other purpose. Guidance will be offered to contractor in interpretation of plans and specifications to assist them to carry out work. Inspections and directives given to contractor does not relieve contractor and his agent, servants and employee of their responsibility to erect and install work in its parts in a safe and workmanlike, and in accordance with the plans and specifications, nor impose upon the Engineer any responsibility to supervise or oversee erection or installation of any work.

III. The location, arrangement and connection of equipment and materials as shown on the drawings, represent a close approximation to the intent and requirement of the work. The right is reserved by the consultant to make consultant to make responsible changes required to accommodate conditions arising during the progress of the work, at no extra cost to the owner.

\section{Category 7/Shop finish}

I. Unfinished work will be listed as deficiencies.

\section{Category 8/Temporary or trial usage, testing}

I. It is agreed and understood, that no claim for damage will be made for any injury or breakage to any part or parts of above due to aforementioned tests, whether caused by weakness or inaccuracy of parts, or by defective materials or workmanship of any kind whatsoever. Supply all labour and equipment for such tests. Take responsibility for damage caused by defective materials or workmanship during temporary or trial usage by owner.

Daylath MENDIS. Is a PhD student under Dr Kasun Hewage's supervision. His doctoral work is to develop a Project Delivery and Contract Strategy (PDCS), with a focus on life cycle costing (LCC), to manage immediate and post-disaster construction activities. He has over 15 years of industrial work experience in Civil Engineering. He has earned a Master's degree in Civil Engineering from the University of British Columbia in 2011. His Master's research work was focused on contractual obligations in construction waste management.

Kasun HEWAGE. Is a Professional Engineer with multi-disciplinary project experiences. He earned his PhD in Project Management from the University of Calgary (Uof C), Canada. At present, he is serving as a Faculty Member in the School of Engineering at the University of British Columbia (UBC), Canada. Prior to his appointment at UBC, he worked as a Business Management Cost Specialist and a Civil Engineer. He holds memberships in wide range of professional associations, including the Association of Professional Engineers and Geoscientists in British Columbia. His current research focuses are on green construction, waste management, and sustainability. A detailed list of Dr. Hewage's publications can be found at: www.ubc.ca/okanagan/engineering/faculty/kahewage.html.

Joanna WRZESNIEWSKI. Is the Principal of the law firm Kimmitt Wrzesniewski. She is involved in various professional organizations and currently sits on the board of the Okanagan Mortgage Lenders Associations (OMLA) and the Kelowna Estate Planning Society (KEPS). She is also the chair of the Commercial and Real Estate Okanagan Section of the Canadian Bar Association. Her profile can be found at http://www.kimmitt.ca/joanna-wrzesniewski/. Her areas of practice include commercial and residential real estate, real estate development, strata property law, corporate law, wills and estates, and civil litigation with a focus in the area of personal injury law. 